\title{
Konservasi Cagar Budaya dengan Asap Cair
}

\author{
Moh. Habibi, Dian Eka P., Arif Gunawan, Heri Yulianto, Wahyudi
}

Balai Konservasi Borobudur

Email : habib1_m@yahoo.com

\begin{abstract}
Abstrak : Jamur dan rayap adalah organisme yang menyebabkan pelapukan pada cagar budaya kayu. Penelitian ini bertujuan untuk mengetahui efektifitas asap cair untuk bahan konservasi cagar budaya kayu. Pengujian yang dilakukan meliputi antijamur dan antirayap. Bahan baku asap cair yang digunakan dari tempurung kelapa. Konsentrasi asap cair yang digunakan untuk antijamur dan antirayap adalah $0 \% ; 7,5 \% ; 15 \% ; 30 \% ; 50 \% ; 100 \%$ $(\mathrm{v} / \mathrm{v})$. Hasil penelitian menunjukkan bahwa asap cair mampu menghambat pertumbuhan jamur dan memiliki daya tolak untuk rayap. Konsentrasi 30\% menunjukkan hasil terbaik sebagai antijamur, sedangkan konsentrasi 50\% merupakan konsentrasi terbaik asap cair untuk antirayap. Semakin tinggi konsentrasi asap cair menunjukkan semakin tinggi efektivitasnya. Kandungan kimiawi fenol dan asam yang berfungsi sebagai antijamur dan antirayap.
\end{abstract}

Kata Kunci : asap cair, antirayap, antijamur

\begin{abstract}
Fungi and termites are organisms that cause decay in wooden cultural heritage. This study aims to determine the effectiveness of liquid smoke for the conservation of wooden cultural heritage. Tests performed include antifungal and antitermites. Liquid smoke was made from the coconut shell. The concentration of liquid smoke is used for antifungal and antitermites is $0 \%, 7.5 \% ; 15 \% ; 30 \% ; 50 \% ; 100 \%(\mathrm{v} / \mathrm{v})$. The results showed that liquid smoke can inhibit the growth of mold and has a thrust for termites. Concentration of $30 \%$ showed the best result as an antifungal, whereas the concentration of $50 \%$ is the best concentration of liquid smoke to antitermites. The higher the concentration of liquid smoke indicates the higher effectiveness. Chemical content of phenol and acid that serves as antifungal and antitermite.
\end{abstract}

Keywords : liquid smoke, antitermites, antifungal

\section{Pendahuluan}

\section{A. Latar Belakang}

Indonesia mempunyai benda cagar budaya yang melimpah. Banyak benda cagar budaya yang ditemukan di Indonesia, baik di daratan maupun di laut. Benda cagar budaya yang ditemukan dapat berupa logam, batuan, keramik, dan kayu. Benda peninggalan yang berupa kayu sangat rentan terhadap degradasi/pengerusakan disebabkan karena faktor biologis, kimiawi ataupun fisik. Hal ini disebabkan karena kayu merupakan benda organik yang dengan mudah dapat menarik mikroorganisme dan serangga.Beberapa permasalahan yang sering terjadi pada benda cagar budaya kayu adalah terjadinya kerusakan struktur morfologi dan anatomi dari kayu itu sendiri. Degradasi morfologi dan anatomi kayu disebabkan karena 2 faktor, yaitu faktor biologis dan non biologis. Faktor biologis seperti pengerusakan yang disebabkan oleh rayap (Anon, 1969) hewan penggerek, jamur, dan bakteri (Tobing, 1977). Beberapa jenis fungi pada benda cagar budaya kayu yang telah berhasil diidentifikasi adalah dari genus Penicillium sp., Cladosporium sp., Aureobasidium sp., dan Eupenicillium sp., (Ortiz et al., 2014), sedangkan rayap yang umum menyerang kayu adalah rayap kayu kering (Cryptotermes spp.) dan rayap tanah (Macrotermes spp.) (Wijaya et al., 2008).Sedangkan yang dimaksud dengan pengerusakan kayu yang disebabkan oleh faktor non biologis adalah semua faktor yang dapat merusak kayu selain organisme. Kerusakan-kerusakan tersebut meliputi kerusakan mekanis, fisis, dan kimiawi.

Usaha konservasi dan preservasi kayu telah banyak dilakukan. Konservasi benda cagar budaya kayu dengan memanfaatkan bahan tradisional sedang banyak dikembangkan. Salah satu bahan tradisional yang telah banyak digunakan sebagai pengawet kayu adalah asap cair. Asap cair juga banyak digunakan sebagai pengawet makanan. Komponen utama penyusun asap cair adalah fenol 4,13\%, asam 10,2\%, dan karbonil 11,3\% (Wagiman et al., 2014).Asap cair merupakan produk hasil hasil pembakaran kayu atau biomassa dengan cara pirolisis menggunakan suhu tinggi tanpa udara (Lee et al., 2011). Kayu sebagai bahan bakar umumnya tersusun atas komponen utama yaitu selulosa, hemiselulosa, dan 
lignin (Maga, 1987). Proses pirolisis melibatkan reaksi dekomposisi, oksidasi, polimerisasi, dan kondensasi (Girard, 1992).

Asap cair yang diperoleh dari pirolisis tempurung kelapa memiliki kandungan senyawa fenol sebesar 4,13\%, karbonil 11,3\%, dan asam 10,2\% (Darmadji, 1996). Sedangkan Luditama (2006) mengungkap bahwa kandungan asap cair tempurung kelapa dan sabut kelapa terdiri dari fenol 31,93-44,30\% di mana luas area tertinggi di dapat pada hasil pirolisis sabut kelapa pada suhu $500^{\circ} \mathrm{C}$. Senyawa dominan lainnya yaitu 2,6 dimetoksi fenol dan 1,2 benzenediol dengan luas area yang juga bervariasi tergantung dari masing-masing sampel dan suhu yang digunakan. Senyawa yang sangat berperan sebagai antimicrobial adalah senyawa fenol dan asam asetat, dan peranannya semakin meningkat apabila kedua senyawa tersebut ada bersama-sama.Mutu dan kualitas asap yang dihasilkan tergantung dari jenis kayu, kadar air, dan suhu pembakaran yang digunakan dalam proses pengasapan. Untuk mendapatkan mutu dan volume asap sesuai yang diharapkan digunakan jenis kayu keras (non-resinous) seperti tempurung kelapa. Bila menggunakan kayu yang lunak (resinous), asap yang dihasilkan banyak mengandung senyawa dan bau yang tidak diharapkan. (Eddyet al., 1993).

Berdasarkan hal tersebut, perlu dilakukan penelitian tentang efektivitas asap cair sebagai bahan preservasi benda cagar budaya berbahan kayu. Penelitian ini focus pada pengujian antijamur dan antirayap.

\section{B. Ruang Lingkup Kajian}

Ruang lingkup kajian Konservasi Cagar Budaya Kayu dengan Asap Cair ini dibatasi pada percobaan laboratorium untuk mengetahui efektivitasnya dalam menghambat serangan rayap dan jamur pada kayu.

\section{Jenis dan Sumber Data}

Jenis data yang digunakan dalam penelitian ini adalah data kualitatif dan kuantitatif. Data kualitatif diperoleh melalui observasi lapangan pada rumah adat kayu yang terawetkan oleh jelaga asap di Kupang, NTT. Sedangkan data kuantitatif meliputi luasan zona hambat dan mortalitas rayap.

Sumber data primer berupa pengujian asap cair terhadap mortalitas rayap dan luasan zona hambat. Sumber data sekunder dapat berupa artikel, jurnal, dan laporan hasil kajian terdahulu.

\section{Metode Pengumpulan Data}

Metode pengumpulan data yang digunakan dalam kajian ini meliputi observasi, wawancara, dan eksperimen. Metode observasi dilakukan dengan cara mengunjungi daerah Kupang yang telah menggunakan metode pengasapan untuk mengawetkan cagar budaya kayu, mengunjungi tempat produksi asap cair untuk mengetahui cara membuat asap cair, dan melakukan pengamatan secara langsung terhadap pengaruh asap cair terhadap mortalitas rayap.

\section{E. Pengujian Antirayap}

Rayap yang digunakan pada kajian ini adalah rayap kayu kering (Cryptotermes spp.). Metode pengujian yang digunakan adalah metode pengumpanan. Tahapan pengujian meliputi :

a. Persiapan umpan

Sebelumnya, kertas umpan di sesuaikan ukurannya dengan gelas plastik sebagai tempat uji. Yang dijadikan sebagai umpan adalah kertas saring yang mengandung selulosa. Kertas saring selulosa dioven pada suhu $103 \pm 2^{\circ} \mathrm{C}$ sampai konstan sebelum pengolesan asap cair.

b. Pengolesan

Kertas saring yang telah disesuaikan ukurannya dengan botol kaca, diolesi asap cair dengan konsentrasi $0 \% ; 7,5 \% ; 15 \% ; 30 \% ; 50 \%$ dan 100\%. Setelah itu, kertas saring dikeringkan.

c. Pengumpanan rayap

Kertas saring diletakkan di dasar botol sampel dan diusahakan bagian dasar tertutup rata oleh kertas saring. Setiap variasi konsentrasi dilakukan tiga kali ulangan. Masing-masing gelas diisi dengan 10 ekor rayap kayu kering, kemudian ditutup secara hati-hati dengan kertas saring yang kedua sehingga posisi rayap berada diantara kertas saring. Gelas yang sudah berisi rayap diletakkan di tempat gelap dan kering.

d. Pengamatan

Pengamatan pengumpanan dilakukan selama 30 hari. Rayap kayu kering yang mati selama penelitian dikeluarkan setiap hari dan dicatat. Setelah 30 hari kertas saring dan rayap 
dikeluarkan dari gelas. Kertas saring dibiarkan diudara terbuka sampai kering angin, kemudian ditimbang kembali untuk menentukan berat yang berkurang selama pengumpanan.

e. Perhitungan Nilai Mortalitas Rayap

Nilai mortalitas dihitung dengan rumus sebagai berikut:

Mortalitas rayap (\%) :

$\frac{\left(\sum \text { Rayap yang mati) }\right.}{\left(\sum \text { Total Rayap }\right)} \times 100 \%$

Nilai mortalitas dihubungkan dengan dengan $\mathrm{LC}_{50}$

f. Perhitungan Persentase Penurunan Berat Uji Persentase penurunan berat uji dihitung dengan persamaan sebagai berikut:

$$
A=\frac{B o-B 1}{B o} \times 100 \%
$$

Keterangan :

$\mathrm{A}=$ Persentase penurunan berat $(\%)$

Bo $=$ Berat sebelum pengumpanan $(\mathrm{g})$

$\mathrm{B} 1$ = Berat setelah pengumpanan $(\mathrm{g})$

Sedangkan untuk pengujian antijamur asap cair dilakukan melalui dua tahap, yaitu tahap pertama isolasi dan identifikasi jamur yang diperoleh dari cagar budaya kayu. Tahap kedua dilakukan pengujian antijamur.

a. Isolasi dan Identifikasi Jamur

Jamur uji diperoleh dari salah satu koleksi Museum Kupang, Nusa Tenggara Timur. Jamur diambil dengan cara mengoleskan cotton bud yang telah disterilisasipada koleksi yang berjamur. Setelah itu dimasukkan ke dalam aluminum foil untuk diidentifikasi di Laboratorium Biologi, Balai Konservasi Borobudur. Cotton bud di oleskan pada medium PDA, lalu diinkubasikan selama tujuh hari pada suhu kamar $\left(28^{\circ} \mathrm{C}\right)$ (Oramahi et al., 2006; Oramahi, 2008).

Identifikasi dilakukan dengan cara sebagai berikut : biakan murni yang diperoleh pada medium PDA dipindahkan ke cawan petri yang berisi medium PDA lainnya. Pemindahan biakan murni ke medium PDA dalam bentuk suspensi spora. Pembuatan suspensi spora menggunakan medium agar air $(0,2 \%)$ dan Tween 80
(0,05\%) (Pitt \& Hocking, 1997). Identifikasi terhadap jamur hasil isolasi dilakukan dengan mengamati koloni (karakteristik makro) dan karakteristik mikro (spora). Preparat diamati secara mikroskopis dengan mengacu pada sifatsifat morfologi jamur.

b. Aktivitas Antijamur Asap Cair

Efikasi aktivitas antijamur asap cair serbuk gergaji dilakukan dengan menggunakan peracunan makanan. Pengujian antijamur asap cair dilakukan secara in vitro dengan mengacu pada Yoshimoto dan Syafii (1993) yang dimodifikasi. Petri dish yang sudah disterilkan diisi dengan media PDA masing-masing $10 \mathrm{ml}$. Lalu biakan murni jamur diinokulasi pada petri dish. Kemudian potongan kertas saring yang telah direndam pada berbagai macam konsentrasi asap cair $(7,5 \% ; 15 \% ; 30 \% ; 50 \% ; 100 \%)$ dan diinkubasi pada suhu kamar. Pengamatan dilakukan terhadap pertumbuhan koloni jamur dengan mengukur diameter koloni pada hari ke 2, 3, 4, 5, 6 dan 7 setelah inokulasi. Efikasi aktivitas antijamur dinyatakan dengan indeks antijamur (Velmurugan et al., 2009) dengan persamaan sebagai berikut:

Indeks antijamur $=(1-\mathrm{Dt} / \mathrm{Dc}) \times 100 \%$

Keterangan:

$\mathrm{Dt}=$ diameter koloni jamur perlakuan

$\mathrm{Dc}=$ diameter koloni jamur kontrol

\section{F. Metode Analisis}

Pengujian antirayap dan antijamur dilakukan 3 kali pengulangan. Selanjutnya data yang telah diperoleh diolah dengan menggunakan RAL (Rancangan Acak Lengkap). Pengaruh perlakuan terhadap respon dilihat dari uji ANOVA menggunakan program excel. Uji lanjutan dengan menggunakan uji BNT (Beda Nyata Terkecil). Pengujian LC $_{50}$ dengan menggunakan analisis probit.

\section{Pembahasan}

\section{A. Identifikasi Jamur}

Berdasarkan hasil identifikasi secara makroskopis dan mikroskopis, dapat diketahui bahwa isolate jamur 
yang diperoleh dari koleksi Museum Kupang tergolong ke dalam jamur Aspergillus sp. Koloni jamur dapat dilihat pada gambar 5.1 di bawah ini:

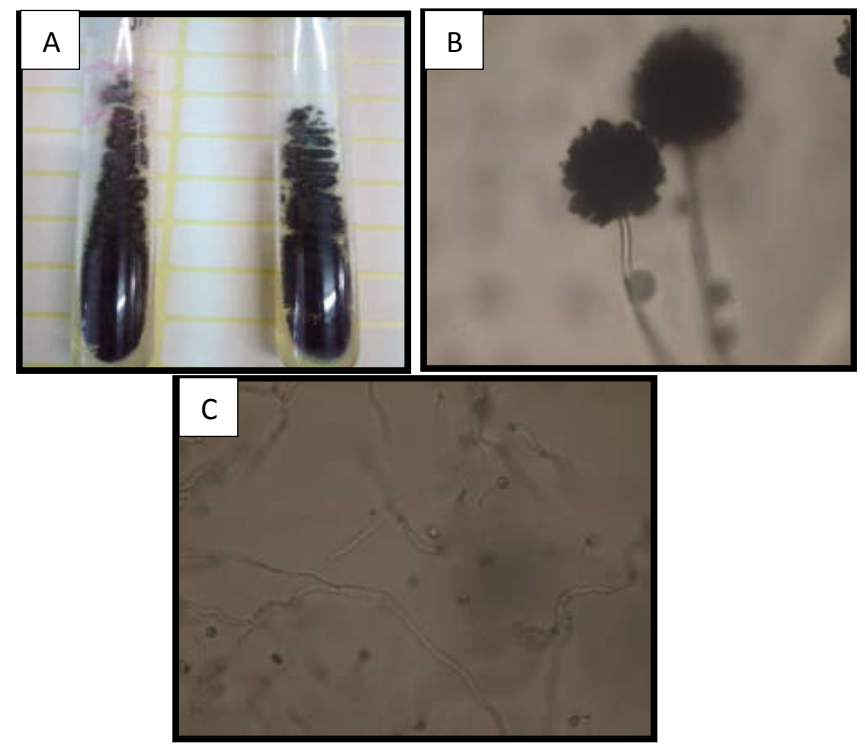

Foto 1. Koloni dan konidia Aspergillus sp. (A) Koloni jamur Aspergillus sp. (B) Hifa dan konidia jamur Aspergillus sp. (C) Spora jamur Aspergillus sp (dok: BKB).

Ciri makroskopis jamur Aspergillus sp. adalah warna basal koloni berwarna putih, bagian yang mengandung konidia berwarna hijau kehitaman. Sedangkan ciri mikroskopis meliputi bentuk konidia bulat, dinding konidiofor tipis dan berwarna putih, vesikel tertutupi oleh sel konidia, dan metula berukuran 3-5 (Barnelt, 1960).

\section{B. Pengujian Efektivitas Antirayap}

Pengujian asap cair sebagai agen antirayap memberikan hasil bahwa asap cair efektif membunuh rayap kayu kering, baik berdasarkan mortalitas rayap kayu kering maupun penurunan berat kertas uji. Mortalitas rayap akibat perlakukan berbagai macam konsentrasi asap cair terlihat seperti pada gambar di bawah ini:

Hasil analisis dengan menggunakan uji ANOVA menunjukkan bahwa asap cair berpengaruh nyata terhadap mortalitas rayap $(\phi<0,05)$. Uji lanjut $\mathrm{BNT}$ memberikan hasil perlakuan terbaik selain konsentrasi 100\% adalah 50\%. Sedangkan konsentrasi 30\% tidak memberikan perbedaan nyata secara signifikan dengan konsentrasi $15 \%$ \& 7,5\%. Hal ini menunjukkan bahwa semakin tinggi konsentrasi asap cair, semakin tinggi mortalitas rayap. Hal ini sejalan dengan semakin tinggi konsentrasi asap cair, semakin tinggi pula komponen dalam asap cair

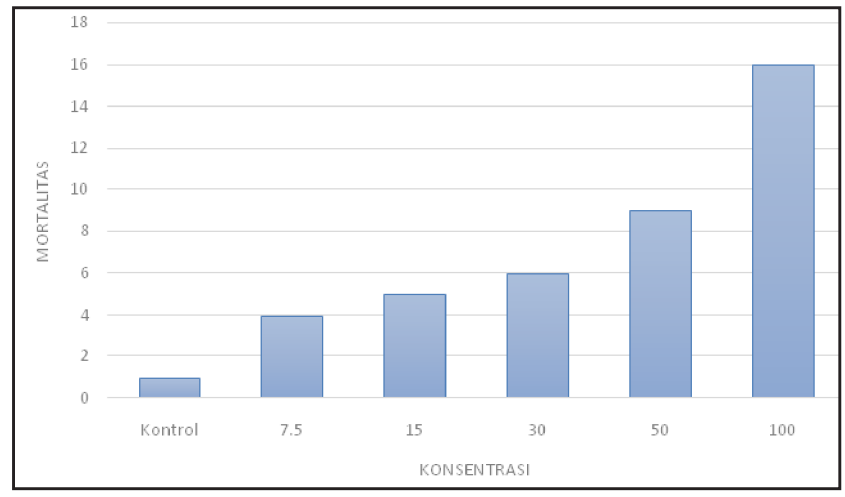

Grafik 1. Pengaruh Konsentrasi Asap Cair Terhadap Mortalitas Rayap.

yang berfungsi sebagai antirayap. Menurut Yatagi et al., (2002) menyatakan bahwa konsentrasi asap cair yang tinggi mengakibatkan kematian rayap meningkat karena kemampuan bahan aktif dalam asap cair, terutama asam asetat juga semakin banyak.

Pengujian asap cair pada kajian ini menggunakan asap cair produksi CV. Al Madaniah, Bantul-Yogyakarta. Berdasarkan hasil study banding ke produsen asap cair tempurung kelapa tersebut, diketahui bahwa suhu pirolisis yang digunakan adalah $120^{\circ} \mathrm{C}$ selama 90 menit. Sehingga kemungkinan komponen aktif yang ada pada asap cair yang dihasilkan belum optimal. Menurut Nakaiet al., (2005) menyatakan bahwa suhu pirolisis berpengaruh terhadap kandungan senyawa aktif yang dihasilkan. Suhu pirolisis dibawah $300^{\circ} \mathrm{C}$ dan di atas $500^{\circ} \mathrm{C}$ menghasilkan asap cair lebih rendah daripada suhu $450^{\circ} \mathrm{C}$. Hal ini dapat disebabkan karena pada suhu yang rendah dimungkinkan belum terjadinya pirolisis secara sempurna, sehingga asap cair yang dihasilkan sedikit. Sedangkan pada suhu yang tinggi, dimungkinkan terjadinya dekomposisi kedua (secondary decomposition). Oleh karena itu, pada penelitian ini dibutuhkan konsentrasi asap cair yang tinggi untuk dapat mulai membunuh rayap kayu kering.

Hasil yang sama ditunjukkan pada analisis penurunan berat kertas uji. Berikut ini diagram pengaruh konsentrasi asap cair terhadap penurunan berat kertas uji:

Penurunan berat kertas saring terkecil selain konsentrasi 100\% adalah konsentrasi 50\%. Berdasarkan hasil tersebut menunjukkan bahwa makin tinggi konsentrasi asap cair makin rendah persentase penurunan berat kertas saring. Hal ini berhubungan dengan aktivitas makan rayap dalam mengkonsumsi kertas saring. 


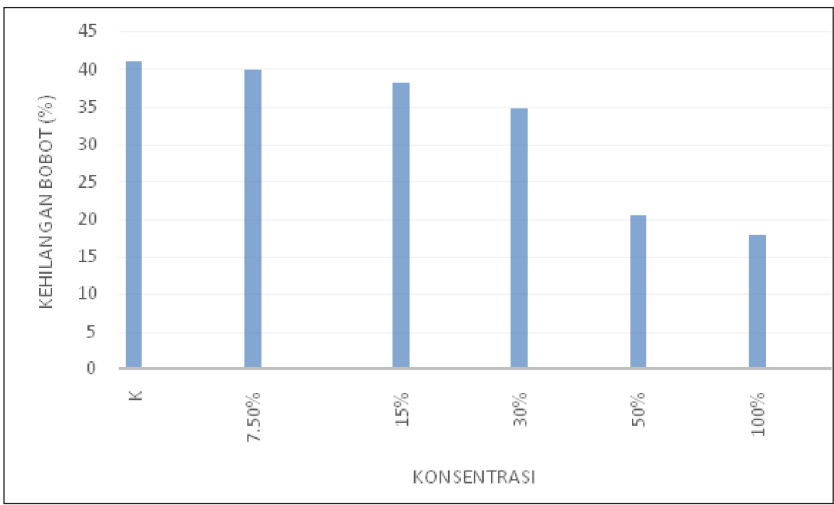

Grafik 2. Pengaruh Konsentrasi Asap Cair (\%) terhadap kehilangan berat kertas saring.

Kemampuan rayap untuk hidup dipengaruhi oleh kemampuan rayap untuk tetap memakan kertas saring. Kertas saring dengan konsentrasi asap cair rendah tetap dikonsumsi oleh rayap, hal ini dikarenakan konsentrasi senyawa aktif yang berfungsi sebagai antirayap rendah, sehingga rayap tetap memakan kertas saring dan tetap hidup. Penelitian yang dilakukan oleh Oramahi \& Yoshimura (2013) menggunakan asap cair dari kayu Laban menunjukkan hasil bahwa pada konsentrasi 1\%5\% terhadap rayap Reticulitermes speratus menyebabkan penurunan berat kertas saring sebesar $6,7 \%-23,7 \%$.

\section{Pengujian Efektivitas Antijamur}

Hasil analisis sidik ragam menunjukkan bahwa konsentrasi asap cair berpengaruh nyata terhadap indeks antijamur. Makin tinggi konsentrasi asap cair makin tinggi indeks antijamur.
Aktivitas antijamur asap cair disebabkan karena adanya komponen asam asetat dan senyawa fenolik. Menurut Velmurugan et al., (2009) menyatakan bahwa komponen 2,6 dimethyl phenol, dehydroacetic acid, dan 2, 3, 5 trimethoxytoluene dalam asap cair serbuk gergaji bamboo mampu berperan sebagai antijamur. Sedangkan Noor et al., (2014) melakukan identifikasi komponen kimiawi asap cair dan menghasilkan bahwa komponen kimiawi dominan asap cair tempurung kelapa pada suhu pirolisis $500^{\circ} \mathrm{C}$ adalah fenol, 2,6-dimethoxy fenol, 2-methoxy fenol, 1,2-benzenediol, dan 3-methoxy-1,2-benzenediol.

Sifat antimikrobia asam asetat terkait dengan kondisi $\mathrm{pH}$. Asam asetat yang tidak terdisosiasi lebih cepat berpenetrasi ke dalam sel. Sedangkan asam propionate mampu menghambat mikrobia dengan cara memblok system metabolisme sel melalui penghambatan kerja

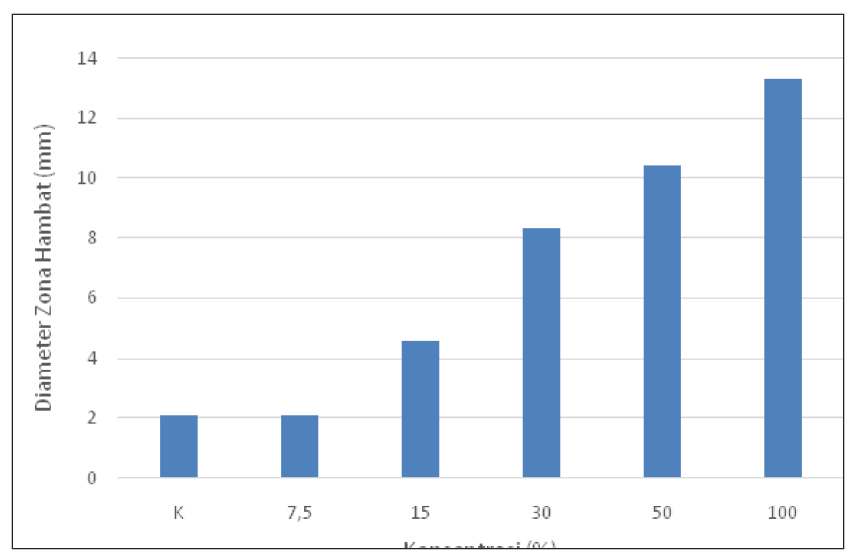

Grafik 3. Diagram pengaruh konsentrasi asap cair terhadap pertumbuhan jamur Aspergillus sp.
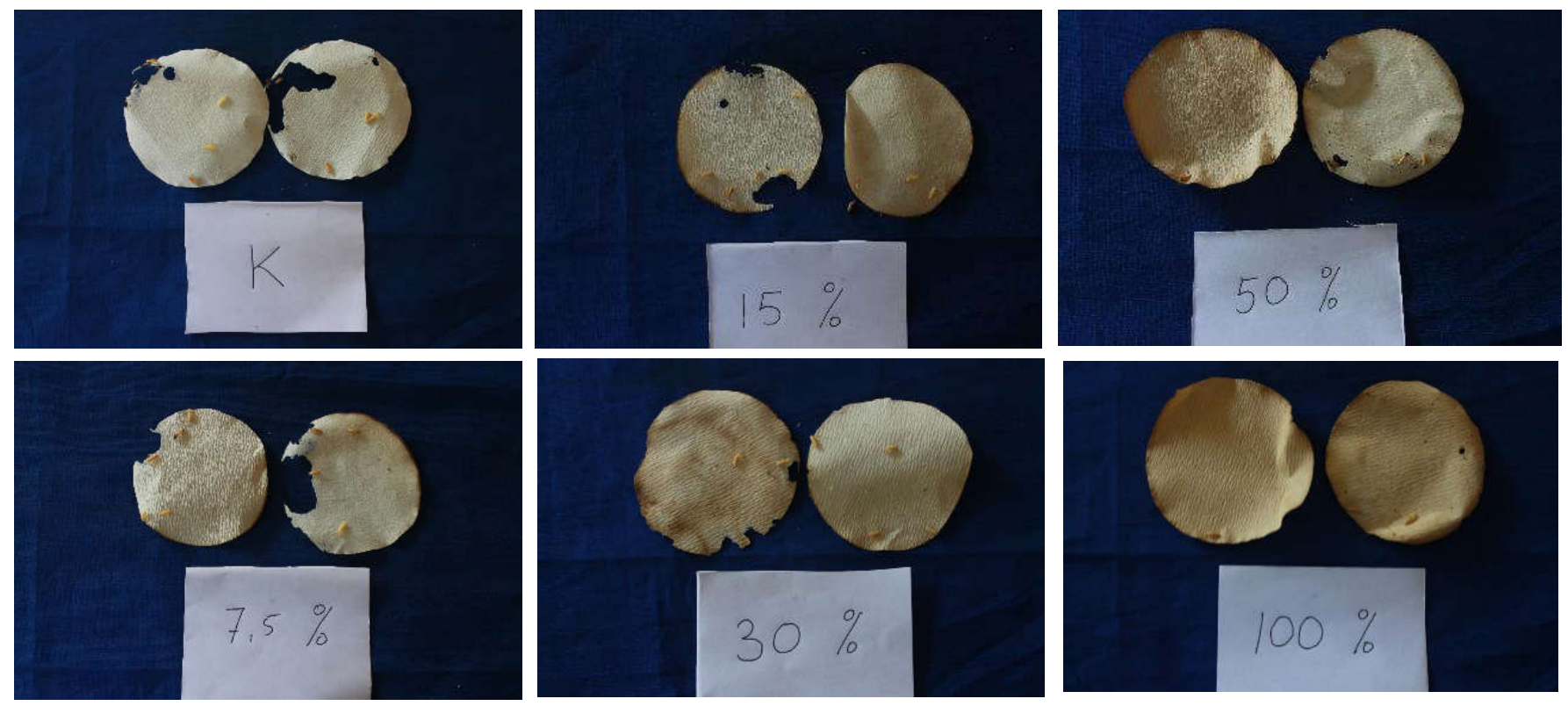

Foto 2. Kertas saring setelah percobaan pengumpanan rayap (dok: BKB). 
enzim di dalam jamur (Karseno et al., 2001). Mekanisme senyawa fenolik sebagai antijamur adalah senyawa fenolik mampu bereaksi dengan membrane sel. Reaksi tersebut menyebabkan permeabilitas membrane sel meningkat, sehingga menyebabkan isi sel keluar, inaktivasi enzimenzim esensial, dan inaktivasi fungsional materi genetic (Davidson\& Banen, 1993).

Hasil penelitian juga menunjukkan bahwa diperlukan konsentrasi yang tinggi untuk menekan pertumbuhan jamur Aspergillus sp.. Menurut Shiah et al. (2006) pada konsentrasi yang tinggi berarti kandungan bahan aktif di dalam asap cair juga tinggi, sehingga lebih banyak bahan aktif yang dapat mengganggu metabolisme di dalam jamur.

\section{Perhitungan $\mathrm{LC}_{50}$}

$\mathrm{LC}_{50}$ (median lethal concentration) adalah konsentrasi yang menyebabkan kematian sebanyak 50\% dari organisme uji yang dapat diestimasi dengan grafik dan perhitungan pada suatu waktu pengamatan tertentu. Berdasarkan hasil perhitungan $\mathrm{LC}_{50}$ untuk pengaruh asap cair terhadap mortalitas rayap, diketahui bahwa toksisitas asap cair tempurung kelapa mempunyai sifat toksisitas rendah (100 ppm<Nilai $\mathrm{LC}_{50}<1000$ ppm). Karena berdasarkan Meyer et al., (1982) mengklasifikasikan tingkat toksisitas suatu ekstrak berdasarkan nilai $\mathrm{LC}_{50}$, yaitu kategori sangat tinggi (bighly toxic) jika mampu membunuh 50\% larva pada konsentrasi 1-10 ppm, sedang (medium toxic) pada konsentrasi 10-100 ppm, dan rendah (low toxic) pada konsentrasi 100-1000 ppm.

\section{Kesimpulan}

Asap cair hasil pirolisis tempurung kelapa efektif digunakan sebagai bahan antijamur dan antirayap secara in vitro. Konsentrasi asap cair berpengaruh nyata terhadap mortalitas rayap kayu kering, kehilangan bobot kertas saring, dan luasan zona hambat. Makin tinggi konsentrasi asap cair makin tinggi mortalitas rayap kayu kering dan makin rendah presentase penurunan bobot kertas saring serta makin luas diameter zona hambat. Hal ini menunjukkan asap cair berpotensi digunakan sebagai bahan konservan untuk benda cagar budaya berbahan kayu.

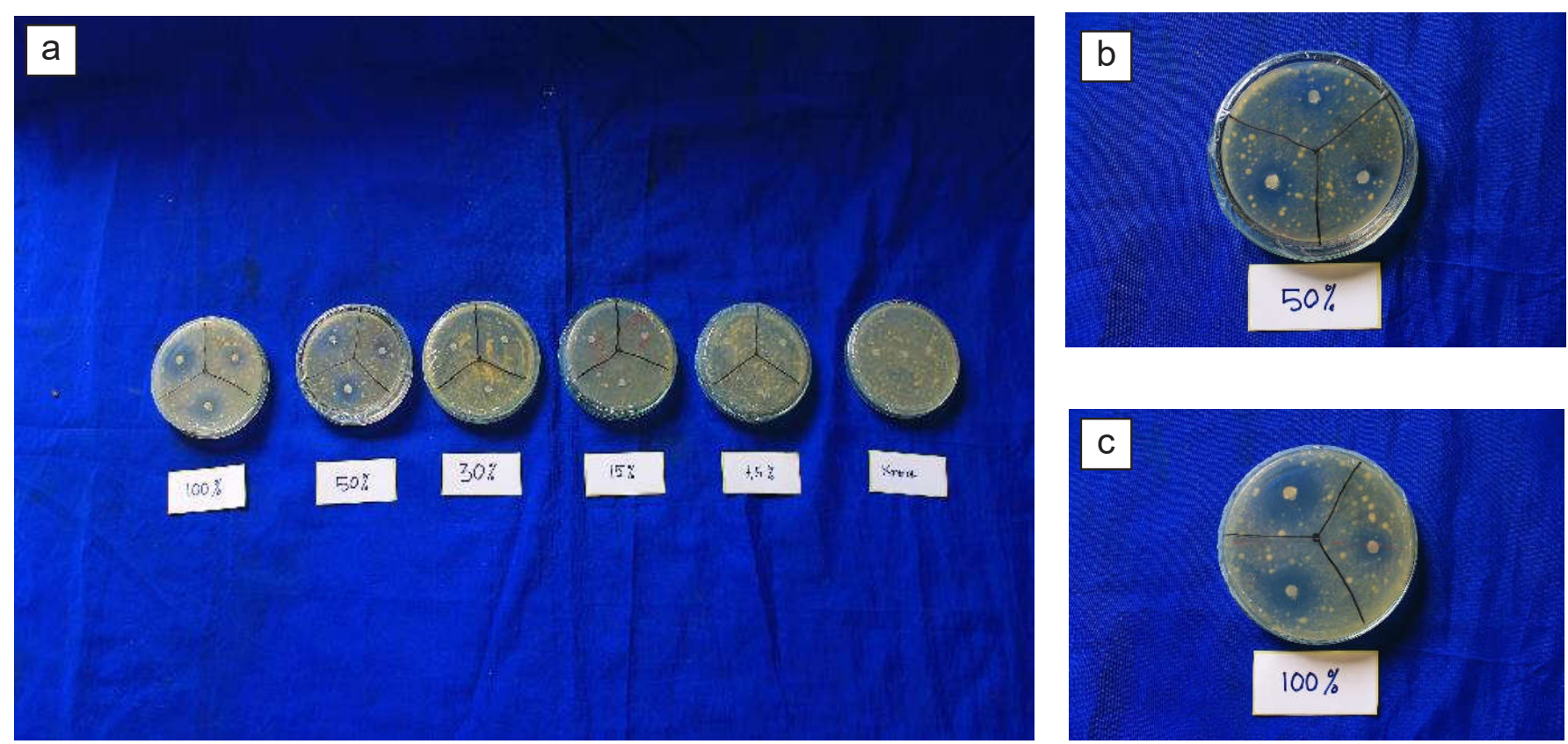

Foto 3. Hasil pengujian antijamur asap cair terhadap jamur Aspergillus sp. a) hasil pengujian pada semua konsentrasi; b) konsentrasi $50 \%$; c) konsentrasi $100 \%$ (dok: BKB). 


\section{DAFTAR PUSTAKA}

Anon. 1969. Methods of Testing Small Clear Specimens of Timber. Indian Standards Institution. New Delhi.

Barnelt, H.L. 1960. Illustrated Genera Of Imperfect Fungi. Departement of Plant Pathology, Bacteriology, and Entomology West Virginia University. Morgantown. West Virginia.

Darmadji, P.1996. Aktivitas antibakteri asap cair yang diproduksi dari bermacam-macam limbah pertanian. Agritech. 16 (4): 19-22.

Davidson, M.P. and Banen, A.L. 1993. Antimicrobial In Food. Second edition Revised. Marcel Decker Inc.: New York.

Eddy, Fretheim, K. Granum, P.E. Vold, E. 1993. Influence of Generation Temperaturon The Chemical Compotition, Antioxidative, and Antimicrobial Effect of Wood Smoke. J.Food Science (45) : 9991003

Girard JP. 1992. Technology of Meat and Meat Product Smoking. Ellis Harwood, New York.

Karseno, Darmadji, P., \& R. Kapti. 2001. Daya Hambat Asap Cair Kayu Karet Terhadap Bakteri Pengkontaminan Lateks dan Ribbed Smoke Sheet. Agritect, 21 (1): 10-15

Lee SH, H'ng PS, Cow MJ, Sajap AS, Tey BT, Salmiah U, \& Sun YL. 2011. Effectivenes s of pyroligeneous acid from vapour released in charcoal industry against biological attacks under laboratory condition. J. Appl. Sci. 11(24): 38483853.

Luditama, Candra. 2006. Isolasi dan Pemurnian Asap Cair Berbaban Dasar Tempurung dan Sabut Kelapa Secara Pirolisis dan Distilasi (Skripsi Sarjana Teknologi Pertanian). IPB. Bogor

Maga, J.A., 1987. Smoke in Food Processing. CRC Press. Inc. Boca Raton. Florida. :1 -3;113-138.

Meyer, B.N., Ferrigni, N.R., Putman, J.E., Jacsben, L.B., Nicols, D.E., and McLaughlin, J.L. 1982. Brine shrimp : a convinient general bioassay for active plant constituent. Plant Medica 45: 31-34.

Nakai, T., Kartal, S., Hata, N., Imamura, Y. (2005): Chemical characterization of pyrolysis liquids of wood-based composites and evaluation of their bio-efficiency. Journal of Building and Environment 95: 41-47.
Noor, E., Luditama, C., Pari, G., 2014. Isolasi dan Pemurnian Asap Cair Berbahan Dasar Tempurung dan Sabut Kelapa Secara Pirolisis dan Distilasi. Prosiding Konferensi Nasional Kelapa VIII.

Oramahi, 2008. Penyakit Simpanan pada Gaplek yang Disebebkan oleb Aspergillus flavus. Disertasi pada Program Studi FitopatologiUniversitas Gadjah Mada (tidak dipublikasikan).

Oramahi, H.A., Sumardiyono, C., Pusposendjojo \& Haryadi. 2006. Identifikasi Jamur Genus Aspergillus pada Gaplek di Kabupaten Gunungkidul, J. Perlindungan Tanaman Indonesia 12 (1): 13-24.

Oramahi HA \& Yoshimura T. 2013. Antifungal and antitermitic activities of wood vinegar from Vitex pubescens Vahl. J. Wood Sci. 59: 344-350

Ortiz, R., Parraga, M., Carrasco, I., Vega, E., Ortiz, M., Herrera, P., Jurgens, J., Held, J., Blanchette, R.. 2014. Investigation of Biodeterioration by Fungi in Historic Wooden Churches of Chile. Microbial ecology. 67(3): 568-575

Pitt. J.I \& A.D. Hocking., 1997. Fungi and Food Spoilage. Academic Press, LondonPszczola, Donald E. 1995. Tour Highlights Production and Uses of Smoke-Based Flavors. Food Technol. 49(1);70-74.

Shiah TC, Wu SK, Huang JC \& Lin HC. 2006. The Fungi Resistance of Bamboo Materials Treated with Bamboo Vinegar Using Soaking Treatment. J. of Agriculture and Forestry NYCU 3(1): 1-22. Tobing, T.L. 1977. Pengawetan Kayu. Lembaga Kerjasama Fakultas Kehutanan IPB; Bogor

Velmurugan, N. Han, S. S. \& Y.S. Lee, 2009. Antifungal Activity of Neutralized Wood Vinegar with Water Extracts of Pinus densiflora and Quercus serrata Saw Dusts, Int. J. Environ. Res., 3(2):167176

Wagiman, FX. A. Ardiansyah, \& Witjaksono. 2014. Activity of Coconut Shell Liquide Smoke as an Insecticide on Rice Brown Planthopper (Nilaparvata lugens). ARPN Journal of Agricultural and Biological Science 9: 293-296.

Wijaya, M., E. Noor, T. Tedja Irawadi, dan G. Pari. 2008. Karakterisasi Asap Cair dan Pemanfaatannya sebagai Biopestisida. Bionature,vol 9(1):34-40. ISSN1411-4720 
Yatagi M, Nishimoto M, Ohira KHT, \& Shibata A. 2002. Termiticidal activity of wood vinegar, its components and their homologues. J. Wood Sci. 48(2):338-342.
Yoshimoto, T. \& W. Syafii, 1993. Extractives from Some Tropical Hardwoods and Their Influnces on the Growth of Wood Decaying Fungi. Journal Tropical Agriculture, 4 (2): 31-35. 